\title{
TARI NAMPYOG DALAM PIODALAN DI PURA SAMUANTIGA DESA ADAT BEDULU, KECAMATAN BLAHBATUH GIANYAR
}

\author{
Oleh: \\ I Gusti Ayu Made Widiantari \\ Universitas Hindu Indonesia \\ e-mail:widiantaris@yahoo.com
}

\begin{abstract}
The sacred dance of Nampyog which is performed at the temple of Samuantiga, Bedulu, Blahbatuh, Gianyar has uniqueness among other dance in Bali 1) Nampyog dance is a dance used as a complement of the series of piodalan ceremony at Pura Samuantiga which means sanctification in the series of the Ida Bhatara will be going to have a process of embodyment (tedun) and neutralizing the mrana (plague) 2) The dancers of the Nampyog dance are marely women who do not experience menstruation anymore (menopause). 3) The dancers of the Nampyog dance are people who commit themselves to dedicate their lifelong as the pengayah 'non-payment workers' called the permas. 4) If the permas are no longer capable of being the pengayah, they will be passed on by their heir (based on descendants) 5) The Nampyog dance is accompanied by several gamelan (gong, angklung) simultaneously by those people who also make ngayah on the piodalan ceremony. 6) This sacred Nampyog dance is performed only on the piodalan ceremony at the temple of Samuantiga, Bedulu, Blahbatuh, Gianyar regency.
\end{abstract}

Keywords: Nampyog Dance, Religious Ceremony

\begin{abstract}
Abstrak
Tari Nampyog yang disakralkan dan dipentaskan di pura Samuantiga desa Bedulu, Kecamatan Blahbatuh, Kabupaten Gianyar mempunyai keunikan-keunikan antara lain 1) tari Nampyog merupakan tarian sebagai pelengkap dari rangkaian upacara piodalan di Pura Samuantiga yang bermakna penyucian dalam rangkaian Ida Bhatara akan tedun dan penetralisir mrana (wabah penyakit) 2) penari tari Nampyog adalah wanita yang tidak mengalami menstruasi lagi (menopause). 3) penari tari Nampyog adalah orang-orang yang berkomitmen untuk menjadi pengayah seumur hidupnya yang disebut dengan permas. 4) apabila pengayah permas ini tidak mampu lagi menjadi pengayah, maka akan diteruskan oleh pewarisnya (berdasarkan keturunan) 5) tari Nampyog ini diiringi oleh beberapa gamelan (gong, angklung) secara bersamaan yang ngayah saat upacara piodalan. 6) tari Nampyog yang disakralkan ini dipentaskan hanya pada saat upacara piodalan di pura Samuantiga desa Bedulu, Kecamatan Blahbatuh, Kabupaten Gianyar.
\end{abstract}

Kata kunci: Tari Nampyog, Upacara Agama

\section{PENDAHULUAN}

1.1 Latar Belakang Masalah

Agama Hindu sebagai agama yang dipenga- ruhi oleh kebudayaan di dalam kehidupan masyarakat Bali merupakan dua fenomena dari satu realita. Jalinan kedua fenomena tersebut (agama dan budaya) sulit dipisahkan, karena 
keduanya hadir bersamaan dalam sistem budaya masyarakat. Hal ini disebabkan pada dasarnya manusia itu selalu menolak keburukan dan selalu mencari kebaikan. Kedua fenomena tersebut membentuk keseimbangan yang dipersepsikan ke dalam ajaran filsafat Tri Hita Karana. Tri Hita Karana mengandung pengertian tiga penyebab kesejahteraan yang bersumber pada keharmonisan hubungan antara manusia dengan Tuhannya (parhyangan), manusia dengan sesamanya (pawongan), dan manusia dengan alam lingkungannya (palemahan) (Ngurah,dkk, 2006:99).

Kebudayaan adalah esensi dari manusia, mencerminkan asalnya, yaitu lingkungan dengan bahasa, tradisi yang sangat kompleks, kepercayaan, dan sistem yang membentuk olahan tuangan yang kaya raya dan menjadi sumber dari mana munculnya seni, keindahan yang membuat hidup sangat berharga. Desakan hati manusia adalah mengarah universal dan bersamaan juga menghormati akarnya dalam berbagai ragam kebudayaan (Mantra,1996: 60).

Menurut Koentjaraningrat (2002: 113), kebudayaan nasional tentu menjadi cermin kepribadian bangsa. Unsur kebudayaan universal merupakan konsep kebudayaan yang sangat luas ruang lingkupnya. Unsur kebudayaan yang paling menonjol sifat khas dan mutu kebudayaannya yaitu kesenian.

Agama merupakan salah satu unsur kebudayaan. Peran agama sangat penting dalam kehidupan manusia dan melestarikan serta mengembangkan seni budaya. Kenyataannya seni budaya tidak bisa dipisahkan dari agama karena seni budaya dan agama merupakan cermin kehidupan masyarakat. Agama sebagai simbolik yang memberikan makna pada kehidupan manusia dan memberikan penjelasan yang paling komprehensif tentang seluruh realitas. Agama merupakan suatu pandangan hidup yang harus diterapkan, baik dalam kehidupan individu maupun kelompok (Kahmad, 2002: 63).

Lebih lanjut Punyatmadja (1989:13), menyatakan bahwa Hindu sebagai agama terdiri atas tiga kerangka dasar, yaitu tattwa, susila, dan upacara. Tattwa merupakan landasan filosofis ajaran agama dan sekaligus digunakan sebagai pandangan hidup. Susila merupakan landasan dan pedoman moral meliputi ajaran tentang tingkah laku. Sedangkan upacara merupakan kebiasaan-kebiasaan dalam kehidupan beraga- ma yang meliputi tradisi aktivitas-aktivitas hidup keagamaan (upacara dan upakara).

Ajaran yang mengandung filosofis atau filsafat (tattwa), nilai etis atau etika (susila), serta nilai ritual yang praktis (upacara) sebagai upaya untuk meningkatkan sraddha dan bhakti umat Hindu (Subagiasta, 2008:12). Ketiga kerangka dasar ini merupakan sistem yang tidak terpisahkan dan selalu dipakai pedoman bagi umat Hindu dalam melaksanakan ajaran agama Hindu. Jika diumpamakan dengan tubuh manusia, maka tattwa (filsafat) disamakan dengan jiwa, etika (susila) sama dengan citta (pikiran) yang dalam waktu-waktu tertentu bisa berubahubah, sedangkan upacara (ritual) sama dengan tangan dan kaki pada manusia.

Upacara merupakan bagian dari tiga kerangka dasar agama Hindu yang bertujuan untuk mencapai kesempurnaan, kebahagiaan, dan kesejahteraan hidup, serta kesucian lahir batin. Ritual agama Hindu sebagai bagian akhir dari tiga kerangka dasar agama Hindu dituangkan dalam pelaksanaan panca yadnya, yaitu: (1) dewa yadnya, korban suci yang dipersembahkan atau dihaturkan sebagai tanda penghormatan kepada para dewa dengan segala manisfestasinya, (2) rsi yadnya, korban suci yang dipersembahkan atau penghormatan kepada para pendeta atau orang yang dianggap suci dan disucikan, (3) pitra yadnya, korban suci yang dipersembahkan kepada leluhur atau orang tua yang sudah meninggal, (4) manusa yadnya, korban suci yang dipersembahkan atau diperuntukkan bagi kesejahteraan manusia (atiti puja), dan (5) bhuta yadnya, korban suci yang dipersembahkan kepada para bhuta kala (Surayin, 2005: 5 ).

Berbhakti kehadapan Ida Sang Hyang Widhi Wasa (Tuhan Yang Maha Esa) adalah salah satu bentuk pengamalan ajaran agama Hindu. Pelaksanaannya dapat dilakukan dengan empat jalan atau cara yang disebut dengan catur bhakti marga terdiri atas: bhakti marga, karma marga, jnana marga, dan yoga marga. Dalam pelaksanaannya, bhakti, karma, dan jnana marga dapat dibedakan dalam pengertiannya saja, akan tetapi pengamalannya merupakan salah satu kesatuan yang tidak bisa dilepaskan. Sebab, bhakti kehadapan Sang Hyang Widhi Wasa yang baik dan benar sudah jelas didasarkan atas jnana (pengetahuan) ajaran dharma dan kesucian sebagai landasannya. Dalam keseharian, dapat ditonjolkan sesuai dengan kemampuan masing- 
masing di antara ketiganya. Ada yang lebih menonjol akan bhaktinya, di lain pihak jnananya yang lebih menonjol karena kemampuannya di dalam hal itu telah dikuasainya, akan tetapi ada yang hanya dengan karma dan perbuatan yang dilakukan sebagai ungkapan bhakti kehadapan Ida Sang Hyang Widhi Wasa yaitu dapat berupa ngaturan ayah saat ada pelaksanaan yadnya (Swastika, 2008: 1).

Lebih lanjut Wiana (2003:1) menguraikan pengertian yadnya yaitu dalam kamus, jata yadnya ada yang mengartikan pemujaan persembahan, kurban suci, upacara korban dan lain sebagainya. Semua kata itu belum dapat menjelaskan arti kata yadnya secara tepat. Di dalam Bhagawadgita yadnya diartikan sebagai suatu perbuatan yang dilakukan dengan penuh keiklasan dan kesadaran untuk melakukan persembahan kepada Tuhan. Dengan demikian ada beberapa unsur yang mutlak yang terkandung dalam yadnya. Unsur-unsur tersebut yaitu adanya perbuatan, ketulus-iklasan, kesadaran dan persembahan atau karya, sreya, budhi dan bhakti.

Jadi, yang diutamakan dalam upacara agama adalah yadnya ketulusikhlasan yang didasarkan pada hati nurani yang suci. Upacara yadnya yang dipersembahkan dengan penuh pengharapan dan bertujuan untuk pamer, lebih-lebih diselenggarakan tidak sesuai dengan sastranya tidak disertai kenyakinan penuh adalah suatu yadnya yang tergolong tidak baik.

Di masyarakat yang sangat kental nuansa religinya akan lahir kreasi-kreasi seni sakral, sedangkan di masyarakat yang tidak menganut agama, tidak dapat diharapkan lahir karya seni yang bernuansa religius (Artadi, 2004: 42).

Parmajaya, (2007: 1) menjelaskan bahwa manusia yang lahir ke dunia, pada dasarnya adalah seniman. Berdasarkan hal itu, maka dapat diasumsikan bahwa setiap manusia yang lahir dan hidup di dunia pasti akan selalu berhubungan dengan dunia seni. Seni itu muncul dari daya estetis manusia. Berbicara masalah seni sakral, banyak kalangan yang menyatakan bahwa seni sakral dibentuk oleh dua aspek, yaitu kreativitas daya seni dan agama. Kedua aspek di atas kadang-kadang sulit untuk dibedakan, mana yang tergolong seni sakral, dan mana yang tergolong seni sekuler. Hal ini dimungkinkan kegiatan seni yang dipentaskan oleh umat Hindu di Bali tidak bisa lepas dari ritual keagamaan yang mendukungnya atau dengan kata lain seke- cil apa pun pementasan kesenian yang dipentaskan oleh umat Hindu, pasti dilengkapi dengan ritual keagamaan atau sesajen yang sekecil apa pun bentuknya.

Agama adalah seni dan seni adalah agama. Seni dan agama identik. Kreativitas kesenian adalah nyolahang sastra. Ungkapan tersebut di atas mengisyaratkan bahwa betapa dalamnya kemanunggalan antara seni dan agama di Bali. Apabila tidak didalami secara sungguh-sungguh, maka sangat sulit dibedakan mana seni dan mana agama karena setiap penyelenggaraan yadnya pasti ada kesenian dan setiap pertunjukan kesenian pasti mengandung atau memuat ajaran-ajaran agama. Inilah inti kemanunggalannya yang harus dipahami secara mendalam. Istilah nyolahang sastra sangat beralasan, karena pentas seni merupakan media penyampaian ajaran agama. Jadi, seni adalah simbol kebenaran, kesucian, dan keindahan (Yuda Bakti, dkk, 2007: 33).

Seni sakral merupakan kesenian yang dipentaskan pada saat-saat pelaksanaan yadnya dan disesuaikan dengan keperluannya. Pementasan seni sakral ini sangat disucikan dan dikeramatkan oleh masyarakat Bali. Dalam masyarakat Bali seni sakral identik dengan tenget atau angker, maksudnya tenget atau angker ini bukan berarti negatif, akan tetapi tenget yang berarti menempatkan suatu kegiatan atau karya seni pada posisi yang tertutup atau tidak ditempatkan/dipentaskan pada sembarang tempat. Hal tersebut dilakukan dengan tujuan agar masyarakat (penyungsung) menghormati secara mendalam seolah-olah para dewa, bhatara, roh leluhur yang berstana di dalam karya seni itu (Yuda Bakti, dkk, 2007:35).

Untuk dapat mengenal berbagai jenis kesenian khususnya seni tari, maka ada tiga fungsi tari yang diklasifikasikan, yaitu 1) tari wali adalah tari yang dipentaskan sebagai pelengkap upacara seperti tari rejang, tari pendet, tari sanghyang, tari baris upacara, dan tari Nampyog, 2) tari bebali adalah tari yang dipentaskan sebagai pengikut upacara seperti tari gambuh dan tari legong, 3) tari balih-balihan adalah tari yang ditarikan sebagai hiburan seperti joged, drama (Bandem 1996:29).

Bertitik tolak dari seni tari khususnya seni tari Nampyog yang disakralkan dan dipentaskan di pura Samuantiga desa Bedulu, Kecamatan Blahbatuh, Kabupaten Gianyar mempunyai 
keunikan-keunikan sebagai berikut.

1) Tari Nampyog merupakan tarian sebagai pelengkap dari rangkaian upacara piodalan di pura Samuantiga yang bermakna penyucian dalam rangkaian Ida Bhatara akan tedun dan penetralisir mrana (wabah penyakit).

2) Penari tari Nampyog adalah wanita yang tidak mengalami menstruasi lagi (menopause). Hal ini dimaksudkan agar kesucian penari tetap terjaga dan dapat mengabdikan dirinya dengan cara terlibat langsung dalam setiap kegiatan pada upacara piodalan (pengayah). Namun tidak menutup kemungkinan seseorang akan menjadi permas apabila sudah kehendak dari Ida Bhatara (Tuhan) walaupun orang yang bersangkutan masih mengalami menstruasi. Di samping itu, orang yang sudah lanjut usia tingkat emosional sudah stabil dan pikiran terfokus untuk ngayah.

3) Penari tari Nampyog adalah orang-orang yang berkomitmen untuk menjadi pengayah seumur hidupnya yang disebut dengan permas. Sebagian besar permas (pengayah perempuan) di pura Samuantiga dikarenakan kaelingan artinya diingatkan/ditunjuk oleh Ida Bhatara (Tuhan). Bagi yang kaelingan tersebut, sebelum menjadi permas mengalami serangkaian peristiwa dan menderita sesuatu penyakit bertahun-tahun. Bahkan secara medis banyak di antaranya dikatakan sudah parah dan sulit untuk disembuhkan. Akan tetapi, setelah menjadi permas, kesembuhan pun diperoleh.

4) Apabila pengayah permas ini tidak mampu lagi menjadi pengayah, maka akan diteruskan oleh pewarisnya (berdasarkan keturunan) dan harus menjalani suatu proses upacara pewintenan, bertujuan untuk membersihkan/ menyucikan diri lahir dan batin secara ritual.

5) Penari memakai kebaya warna putih, kain (kemben) warna hitam, selendang putih, ikat kepala putih dan diselipkan bunga kembang sepatu (wira kesuma) serta membawa tiga batang dupa. Warna putih melambangkan Dewa Siwa, warna hitam melambangkan Dewa Wisnu dan api sebagai sumber kehidupan dewanya
Brahma. Sifat api adalah menerangi atau menyinari. Matahari adalah sumber api alam yang terbesar atau sumber dari segala sumber api. Dalam wewatekan, matahari bernilai 21. Angka 21 kalau diuraikan menjadi $2+1=3$. Angka 3 dalam kehidupan beragama Hindu adalah simbul penyucian.

6) Tari Nampyog ini diiringi oleh beberapa gamelan (gong, angklung) secara bersamaan yang ngayah saat upacara piodalan. Penempatan gamelan tersebut sesuai dengan tempat yang ada, yaitu gamelan gong berada di bale gong (terletak di sebelah Selatan mandala Penataran Agung) dan gamelan angklung berada di bale angklung (terletak di sebelah Utara mandala Penataran Agung). Tarian Nampyog ini dilakukan dengan gerakan sederhana dan lemah gemulai yang diawali dengan ayah penangkilan/ngayah ngigel, ngeberan saet, ngoberan anteng, ngober makedeng, ngombak, ngerejang, dan siat sampian yang dimulai dari mandala Batan Manggis kemudian mengelilingi mandala Penataran Agung dan kembali ke mandala Batan Manggis.

7) Tari Nampyog yang disakralkan ini dipentaskan hanya pada saat upacara piodalan di pura Samuantiga desa Bedulu, Kecamatan Blahbatuh, Kabupaten Gianyar.

Selama ini masyarakat hanya mengenal tari Nampyog sebatas kesenian sebagai pendukung upacara. Dengan adanya keunikan-keunikan tersebut penulis ingin mengetahui dan memberikan pemahaman kepada masyarakat tentang tari Nampyog sebagai salah satu pelengkap pelaksanaan upacara piodalan di pura Samuantiga. Di sini topik yang akan dibahas yakni eksisnya Tari Hampyog dalam piodalan di Pura Samuantiga Desa Adat Bedulu.

\section{PEMBAHASAN}

\subsection{Macam-Macam Gerakan Tari Nampyog}

Kesenian memegang peranan penting dalam kehidupan masyarakat Bali terutama dalam kehidupan keagamaan. Dalam berbagai bidang kesenian, seperti seni tari, seni tabuh, seni suara, seni lukis, dan seni pahat selalu hidup berdampingan dengan kehidupan keagamaan terutama 
agama Hindu di Bali. Banyak kalangan masyarakat Bali yang percaya bahwa upacara keagamaan belum lengkap dan sempurna tanpa kehadiran panca gita atau lima macam bunyi-bunyian yang meliputi : mantra, genta, kidung, kulkul, dan tetabuhan/gamelan. Untuk itu seni pertunjukkan seperti tari, karawitan, wayang, drama, topeng, dan yang lainnya merupakan sumber yang amat penting dalam pelaksanaan suatu upacara (Bandem, 1996:167).

Demikian pula halnya dengan piodalan di pura Samuantiga, pementasan tari Nampyog sangat memegang peranan penting. Tanpa pementasan tari Nampyog upacara yang dilaksanakan belum lengkap dan sempurna. Macam-macam gerakan pementasan tari Nampyog pada pelaksanaan piodalan di pura Samuantiga desa adat Bedulu, meliputi :

1. Ngayah Ngigel atau Ayah Penangkilan, yaitu : menari mengitari areal pura sebanyak tiga kali dengan membawa tiga batang dupa yang bermakna kehikmatan dan pengabdian serta menunjukkan bhakti kehadapan Ida Sang Hyang Widhi Wasa.

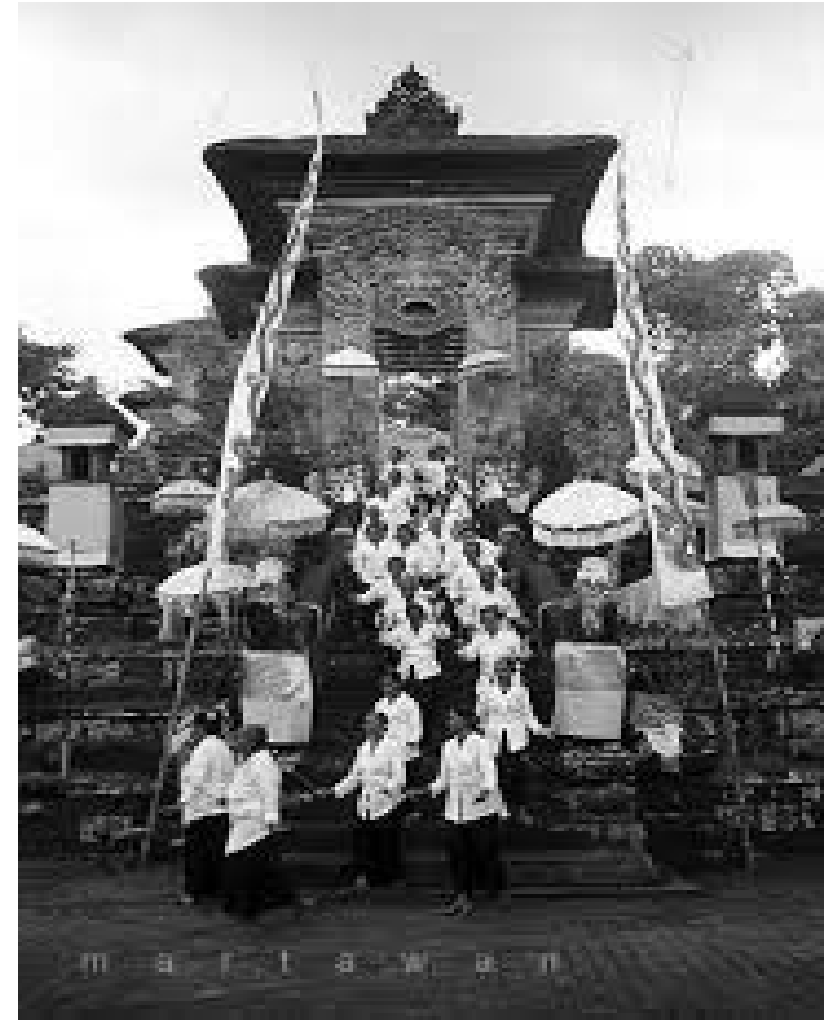

Gambar 2

Ngayah Ngigel/Ayah Penangkilan

2. Ngeberan Saet atau Ngoberan ikat rambut yang berwarna putih terbuat dari kain. Gerakan ngeberan saet ini diikuti oleh para pemangku yang membunyikan genta serta memercikkan tirta atau air suci dan parekan mengelilingi pura sebanyak tiga kali.

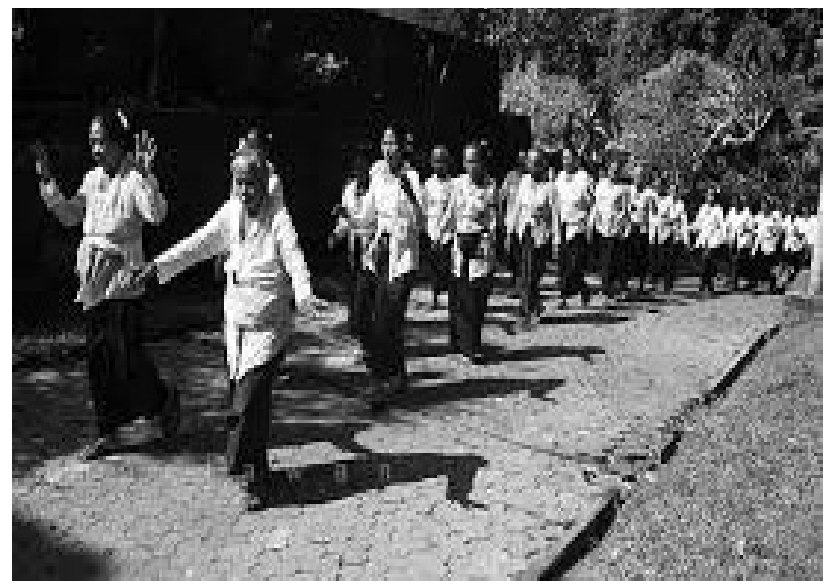

Gambar 3

Ngeberan Saet

3. Ngoberan Anteng, yaitu: gerakan mengibas-ngibaskan selendang yang dipakai dengan mengelilingi pura sebanyak tiga kali. Gerakan ini dilakukan dengan lambat dan lemah gemulai sehingga memberikan rasa ketenangan dan kesucian lahir batin.

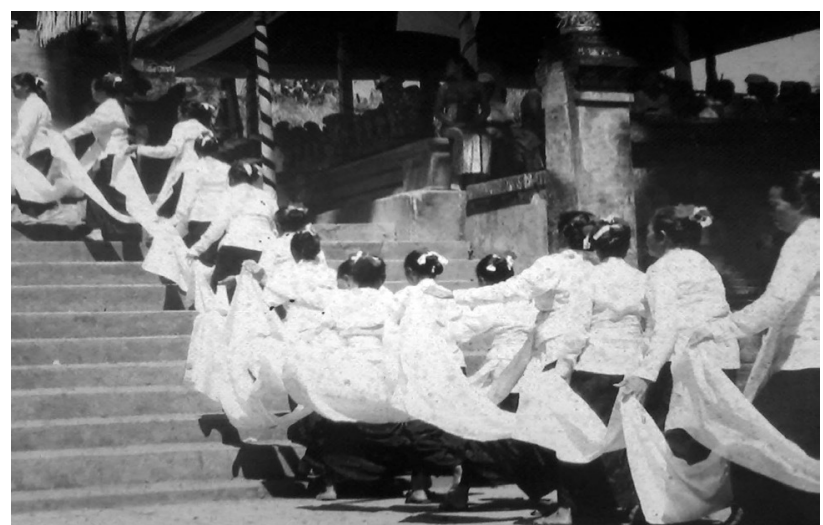

Gambar 4

Ngoberan Anteng

4. Ngober Makedeng, yaitu : selendang permas yang di belakang ditarik oleh permas yang di depannya dan seterusnya mengelilingi areal pura sebanyak tiga kali. Gerakan ini mengandung makna kebersamaan dan meningkatkan rasa kesadaran yakni lebih memahami rasa persatuan dan kesatuan. 


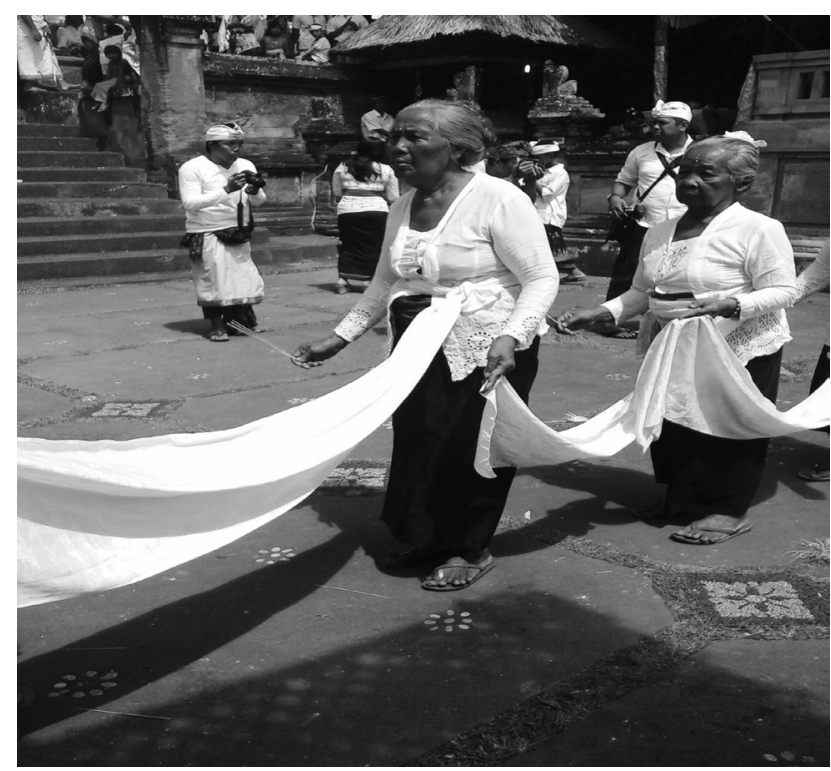

Gambar $\mathbf{5}$

Ngober Makedeng

5. Ngombak, yaitu : suatu gerakan yang dilakukan dengan saling memegang satu dengan yang lainnya. Gerakan ini menyerupai ombak di laut yang bergelombang menyapu pasir-pasir di pantai, memiliki arti penyucian atau pembersihan areal pura dan palinggih.

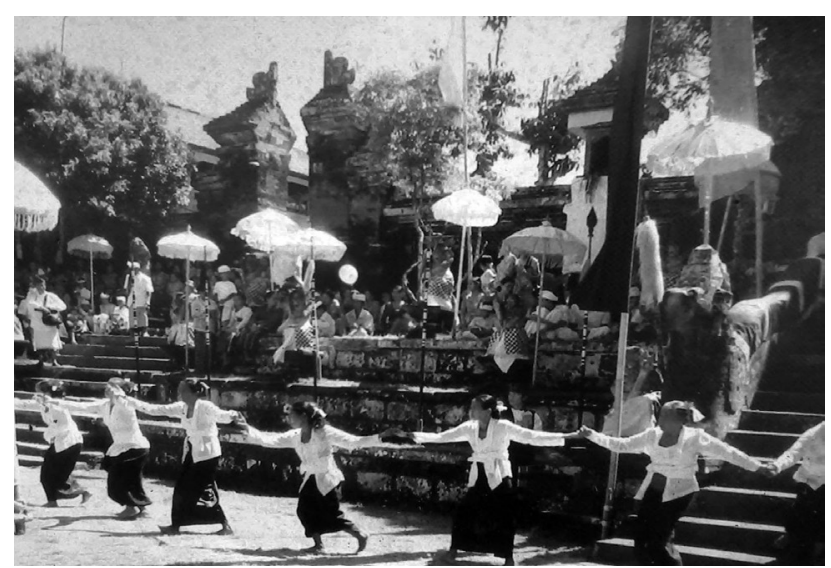

Gambar 6

Ngombak

6. Ngerejang, yaitu : tarian yang mempunyai ciri khas gerakan yang lamban dan lemah gemulai mengikuti irama angklung. Gerakan ini dilakukan dengan suka cita dan penuh ketulusan melaksanakan upacara piodalan.

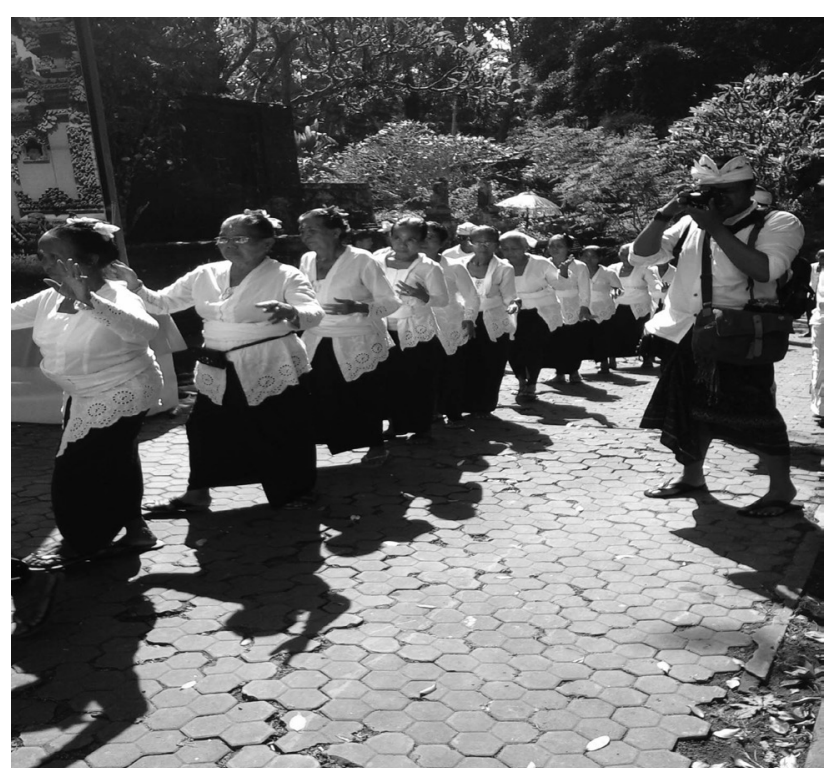

Gambar 7

Ngerejang

7. Siat sampian, yaitu : suatu prosesi terakhir dari rangkaian upacara yang dilakukan oleh permas dan parekan (pengayah laki-laki). Siat sampian atau perang sampian ini dilakukan dengan saling pukul menggunakan sampian dangsil yang telah disiapkan sebelumnya. Para permas dan parekan dengan suka cita dan penuh ketulusiklasan tanpa mengenal lelah melaksanakan siat sampian. Setelah prosesi ini berakhir para permas dan parekan ke Beji melaksanakan pembersihan dan persembahyangan.

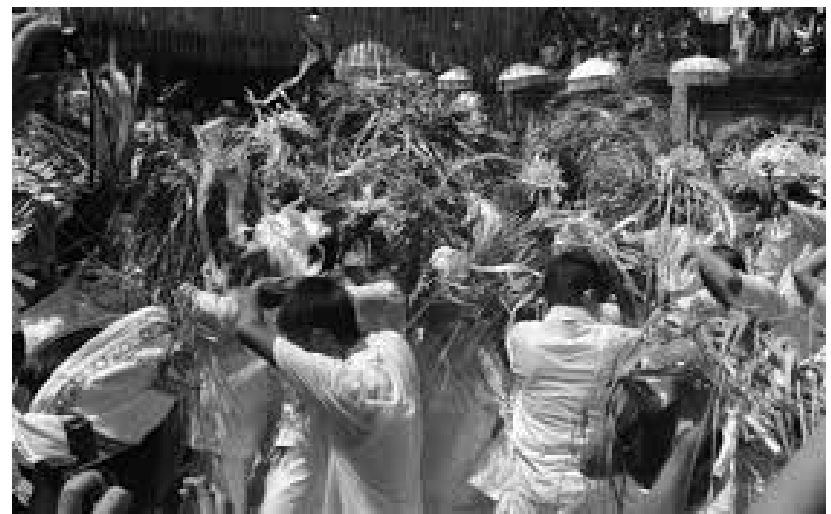

Gambar 8

Siat Sampian

Gerakan pada pementasan tari Nampyog dalam upacara piodalan di pura Samuantiga mempunyai gerak tari yang sangat sederhana, merupakan bentuk tarian kuno yang penuh dengan rasa pengabdian dan rasa ketulusan kepada Ida Bhatara yang berstana di pura Samuantiga. 


\subsection{Penari Tari Nampyog}

Tari Nampyog ditarikan oleh sekelompok penari wanita disebut dengan permas. Permas adalah orang-orang yang berkomitmen dalam hidupnya untuk menjadi pengayah pada setiap upacara piodalan yang berlangsung di pura Samuantiga. Secara hakiki tidak sembarang orang bisa menjadi permas, mereka adalah orang-orang yang menjadi pewaris (berdasarkan keturunan) dan orang-orang yang dikehendaki oleh Ida Bhatara Sesuhunan yang berstana di pura Samuantiga. Berikut ini adalah nama-nama permas yang diperoleh dengan melakukan observasi dan wawancara kepada para penari tari Nampyog di desa Bedulu Kecamatan Blahbatuh, Kabupaten Gianyar dipaparkan dalam tabel sebagai berikut.

Tabel 1

Daftar Permas Generasi Pertama

\begin{tabular}{|c|l|c|l|l|}
\hline No & \multicolumn{1}{|c|}{ Nama } & Umur (Tahun) & \multicolumn{1}{|c|}{ Alamat } & \multicolumn{1}{c|}{ Keterangan } \\
\hline 1 & Jero Keser & 90 & Br. Tengah & Almarhum \\
\hline 2 & Jero Rangke & 97 & Br. Batulumbang & Almarhum \\
\hline 3 & Jero Warsa & 105 & Br. Margabingung & Almarhum \\
\hline 4 & Jero Mas & 90 & Br. Mas & Almarhum \\
\hline 5 & Jero Taman A & 97 & Br. Taman & Almarhum \\
\hline 6 & Jero Taman B & 95 & Br. Taman & Almarhum \\
\hline 7 & Jero GustiTongkol & 95 & Br. Gua & Almarhum \\
\hline
\end{tabular}

Sumber : Hasil Penelitian Tahun 2016

Tabel 2

Daftar Permas yang masih aktif dari desa Pakraman Bedulu

\begin{tabular}{|c|l|c|l|l|}
\hline No & \multicolumn{1}{|c|}{ Nama } & Umur (Tahun) & \multicolumn{1}{|c|}{ Alamat } & \multicolumn{1}{|c|}{$\begin{array}{c}\text { Keterangan } \\
\text { (lama ngayah) }\end{array}$} \\
\hline 1 & Jero Renis Kaca & 80 & Br. Batulumbang & 20 tahun \\
\hline 2 & Jero Suli & 75 & Br. Batulumbang & 22 tahun \\
\hline 3 & Jero Tekek & 75 & Br. Batulumbang & 20 tahun \\
\hline 4 & Jero Tabanan & 50 & Br. Batulumbang & 1 tahun \\
\hline 5 & Jero Resen & 78 & Br. Batulumbang & 20 tahun \\
\hline 6 & Jero Rayu & 50 & Br. Batulumbang & 20 tahun \\
\hline 7 & Jero Suami & 45 & Br. Batulumbang & 2 tahun \\
\hline 8 & Jero Sang Ayu Suci & 60 & Br. Batulumbang & 1 tahun \\
\hline 9 & Jero Karningsih & 55 & Br. Batulumbang & 1 tahun \\
\hline 10 & Jero Renis B & 60 & Br. Batulumbang & 8 tahun \\
\hline 11 & Jero Man Dauh & 70 & Br. Tengah & 10 tahun \\
\hline 12 & Jero Kawit & 70 & Br. Tengah & 4 tahun \\
\hline 13 & Jero Wangi & 60 & Br. Tengah & 19 tahun \\
\hline 14 & Jero Badung & 70 & Br. Tengah & 23 tahun \\
\hline 15 & Jero Timtim & 65 & Br. Lebah & 23 tahun \\
\hline 16 & Jero Molog & 75 & Br. Lebah & 19 tahun \\
\hline 17 & Jero Sari & 65 & Br. Lebah & 18 tahun \\
\hline 18 & Jero Reteg & 65 & Br. Lebah & 22 tahun \\
\hline 19 & Jero Sudi & 50 & Br. Lebah & 1 tahun \\
\hline 20 & Jero Mulikani & 45 & Br. Lebah & 1 tahun \\
\hline 21 & Jero Man Wenten & 55 & Br. Margabingung & 6 tahun \\
\hline 22 & Jero Luki & 70 & Br. Margabingung & 23 tahun \\
\hline 23 & Jero Jenek & 60 & Br. Margabingung & 12 tahun \\
\hline 24 & Jero Purni & 60 & Br. Margabingung & 21 tahun \\
\hline & & & & \\
\hline
\end{tabular}




\begin{tabular}{|l|l|l|l|l|}
\hline 25 & Jero Karsi & 55 & Br. Margabingung & 10 tahun \\
\hline 26 & Jero Latri & 55 & Br. Margabingung & 1 tahun \\
\hline 27 & Jero Tu Alim & 70 & Br. Gua & 19 tahun \\
\hline 28 & Jero Tutik & 47 & Br. Gua & 8 tahun \\
\hline 29 & Jero Rumben & 65 & Br. Gua & 18 tahun \\
\hline 30 & Jero Lipur & 47 & Br. Gua & 5 tahun \\
\hline 31 & Jero Eben & 45 & Br. Gua & 2 tahun \\
\hline 32 & Jero Sukesi & 40 & Br. Gua & 2 tahun \\
\hline
\end{tabular}

Sumber : Hasil Penelitian Tahun 2016

Tabel 3

Daftar Permas yang masih aktif dari luar desa Pakraman Bedulu

\begin{tabular}{|c|l|l|l|l|}
\hline No & \multicolumn{1}{|c|}{ Nama } & Umur (Tahun) & \multicolumn{1}{|c|}{ Alamat } & \multicolumn{1}{|c|}{$\begin{array}{c}\text { Keterangan } \\
\text { (lama ngayah) }\end{array}$} \\
\hline 1 & Jero Biyang Sari & 70 & Br. Tengkulak & 23 tahun \\
\hline 2 & Jero Simpen & 75 & Br. Tengkulak & 23 tahun \\
\hline 3 & Jero Sirat & 70 & Br. Tengkulak & 23 tahun \\
\hline 4 & Jero Kerti & 60 & Br. Tengkulak & 22 tahun \\
\hline 5 & Jero Rubin & 50 & Br. Tengkulak & 5 tahun \\
\hline 6 & Jero Metri & 50 & Br. Tengkulak & 5 tahun \\
\hline 7 & Jero Ubud & 50 & Br. Tengkulak & 1 tahun \\
\hline 8 & Jero Kapal & 47 & Br. Taman & 3 tahun \\
\hline 9 & Jero Suami & 60 & Br. Taman & 18 tahun \\
\hline 10 & Jero Sari & 70 & Br. Taman & 10 tahun \\
\hline 11 & Jero Kisid & 70 & Br. Taman & 15 tahun \\
\hline 12 & Jero Nadi & 70 & Br. Taman & 3 tahun \\
\hline 13 & Jero Nik & 50 & Br. Mas & 5 tahun \\
\hline 14 & Jero Menyol & 60 & Br. Mas & 23 tahun \\
\hline 15 & Jero Mudri & 62 & Br. Mas & 23 tahun \\
\hline 16 & Jero Redi & 50 & Br. Mas & 10 tahun \\
\hline 17 & Jero Kendri & 50 & Br. Mas & 20 tahun \\
\hline 18 & Jero Rubin & 45 & Br. Mas & 15 tahun \\
\hline 19 & Jero Rupig & 70 & Br. Mas & 33 tahun \\
\hline 20 & Jero Anyar & 40 & Br. Mas & 5 tahun \\
\hline 21 & Jero Sekar & 50 & Br. Wanayu & 15 tahun \\
\hline 22 & Jero Balik & 40 & Br. Wanayu & 3 tahun \\
\hline 23 & Jero Tagel & 56 & Br. Wanayu & 20 tahun \\
\hline 24 & Jero Suami & 46 & Br. Wanayu & 3 tahun \\
\hline
\end{tabular}

Sumber : Hasil Penelitian Tahun 2016

\subsection{Eksistensi Tari Nampyog dalam Pio- dalan di Pura Samuantiga}

Berdasarkan hasil studi di lapangan dan mewawancarai penari tari Nampyog dalam hal ini para permas, menyatakan eksisnya tari Nampyog di desa adat Bedulu, Kecamatan Blahbatuh, Kabupaten Gianyar disebabkan oleh beberapa faktor yaitu:

\section{Tari Nampyog sebagai pelengkap upacara}

Pementasan tari Nampyog menurut keteran- gan Patera (dalam wawancara 12 Juni 2016), yaitu sebagai berikut.

"Salah satu bentuk tarian sakral atau suci dibawakan oleh sekelompok penari wanita disebut dengan permas. tari Nampyog ditarikan dalam upacara piodalan di pura Samuantiga sebagai tari pelengkap upacara dan tari penyucian dalam rangkaian Ida Bhatara akan melinggih dan tedun dari Pengaruman Agung. Beranjak dari rangkaian pelaksanaan upacara pio- 
dalan di pura Samuantiga desa adat Bedulu, pada puncak karya yaitu tepat pada purnama kedasa (nemu pasah) ratu manca-manca rauh dari luar desa pangemong seperti pura Penataran Sasih Pejeng, pura Puseh Carangsari Badung dan pura Sidhakarya Badung. Sebelum melinggih di Pengaruman Agung terlebih dahulu dilakukan penyucian dengan tari Nampyog kemudian dilanjutkan dengan prasawiya sebanyak tiga kali, sebelum melinggih ke Pengaruman Agung. Pada hari ke tiga sebelum budal ke pura masing-masing, permas dan parekan melakukan siat sampian yang diawali dengan Nampyog oleh permas".

Sedangkan menurut Jero Renis Kaca (dalam wawancara 12 Juni 2016), yaitu sebagai berikut.

"Prosesi pementasan tari Nampyog dilaksanakan dalam upacara piodalan di pura Samuantiga sebagai tari penyucian dan pengantar persembahan Kehadapan Ida Sang Hyang Widhi Wasa dalam rangkaian ngaturan wali pamuput karya saat Ida Bhatara akan tedun dan melinggih di Pengaruman Agung yaitu pada waktu yang telah ditentukan sekitar pukul 08.00 pagi para penari Nampyog semuanya telah bersiap dan berkumpul untuk melakukan persembahyangan bersamasama yang diawali dari pura Beji, Palinggih Rambut Sedana, Pengaruman Agung, Palinggih Ratu Agung Sakti, dan Palinggih Ratu Agung Panji. Setelah persembahyangan selesai barulah para permas melaksanakan tugasnya dengan menari pada masing-masing palinggih".

Pernyataan Drs. I Wayan Patera, M.Hum dan Jero Made Renis sesuai dengan pendapat Bandem (1996:43) yang menyatakan bahwa tari wali atau sakral merupakan media keagamaan yang sangat penting dan dipertunjukkan dalam upacara keagamaan, sebagai pembersihan.

Dari pernyataan dan hasil wawancara di atas, tari Nampyog merupakan tarian sakral yang harus dilaksanakan karena merupakan tarian pelengkap sekaligus tarian penyucian buana sehingga pengemong pura Samuantiga tidak berani untuk meniadakan tari Nampyog ini. Hal ini menyebabkan eksisnya tari Nampyog dalam upacara piodalan di pura Samuantiga desa adat Bedulu, Kecamatan Blahbatuh, Kabupaten Gianyar.

\section{Penerus tari Nampyog berdasarkan ketu- runan dan orang-orang yang telah dipilih atau menjadi Kehendak Ida Bhatara Sesu- hunan.}

Berdasarkan penjelasan dari mengenai Jero Mudri mengenai tari Nampyog adalah sebagai berikut.

"Saya menjadi permas karena keturunan, meskipun orang tua tidak pernah memberitahukan bahwa saya akan menjadi permas. Pada suatu ketika saya sakit inguh dan nunas raos di Pujung Tegalalang, pada saat itu saya sakit inguh di karenakan kepintelan oleh Ida Bhatara Samuantiga, dari sejak ngayah itulah saya sembuh dari sakit" (wawancara 15 Juni 2016)

Pendapat Jero Mudri sebagai narasumber dalam penelitian ini juga dibenarkan oleh Jero Rupig (wawancara pada tanggal 15 Juni 2016) yang menyatakan bahwa :

"Dulu memang benar leluhur saya menjadi permas. Namun saya tidak melanjutkan ngayah karena saya masih muda dan perlu bekerja untuk menambah penghasilan keluarga. Akan tetapi hidup saya tidak tenang karena hampir tiap malam saya mimpi buruk seperti mimpi dicari oleh orang yang telah meninggal, mata saya dipatuk ular, suami meninggal dan lain-lain. Setelah saya nunas raos dikatakan saya harus menjadi permas karena dulunya leluhur saya adalah pengayah permas di pura Samuantiga. Setelah menjadi permas hidup saya menjadi tenang dan tidak pernah mimpi buruk lagi".

Wawancara dengan Jero Lipur pada tanggal 20 Juni 2016 menyatakan bahwa :

"Saya memimpikan suami tidur di atas penusangan (tempat untuk memandikan dan mengusung mayat). Anehnya tempat penusangan itu di Jaba pura Samuantiga dan mimpinya hampir setiap hari. Seb- 
agai orang Bali saya ingin tahu dengan cara nunas raos. Hasilnya diluar dugaan saya. Karena leluhur saya tidak ada yang menjadi permas. Namun kalau itu sudah menjadi Kehendak Ida Bhatara Samuantiga saya ngiring demi kerahayuan dan keselamatan keluarga saya".

Hal ini sesuai dengan pendapat Gusti Mangku Gede (hasil wawancara pada tanggal 5 Juni 2016) yang menyatakan bahwa :

"Seseorang yang menjadi permas sebagian besar karena keturunan namun ada juga yang menjadi permas karena memang sudah menjadi kehendak Ida Bhatara Sesuhunan pura Samuantiga. Sebelum menjadi permas, orang-orang tersebut banyak yang mengalami sakit yang tidak bisa sembuh meskipun sudah berobat ke dokter. Dan ada juga orang menjadi permas karena mimpi".

Dari beberapa pernyataan dan hasil wawancara di atas, tari Nampyog akan tetap eksis karena adanya faktor keturunan dan masyarakat yang religius tidak akan berani menolak kehendak Ida Bhatara Sesuhunan di pura Samuantiga. Keyakinan ini menyebabkan penari tari Nampyog dalam hal ini permas akan tetap ada dan bertambah sesuai kehendak Ida Bhatara Sesuhunan di pura Samuantiga.

\section{Meningkatkan status sosial di masyarakat}

Wawancara dengan seorang parekan (pengayah laki-laki) yang bernama I Ketut Jedrem pada tanggal 2 Juni 2016 menyatakan bahwa :

"Sebelum menjadi permas, para wanita harus melalui proses pawintenan atau penyucian sekala dan niskala dengan menghaturkan banten pejati dan pemiakala. Para wanita yang telah melalui proses penyucian, selanjutnya dipanggil oleh masyarakat setempat dengan sebutan Jero Permas. Pekerjaan Jero Permas adalah sebagai seruti banten pada saat upacara piodalan di pura Samuantiga. Menjadi permas sangat dihormati oleh masyarakat pengemong dan apabila masyarakat pengemong memerlukan permas untuk membantu membuat sarana upacara, maka masyarakat pengemong harus $m a-$ tur piuning Kehadapan Ida Bhatara Sesuhunan di pura Samuantiga".

Pernyataan I Ketut Jedrem ini dibenarkan juga oleh Ketua Paruman yang bernama Drs. I Wayan Patera, M.Hum, sebagai berikut.

"Menjadi permas dapat meningkatkan
status sosial di masyarakat. Maksudnya
adalah sebelum menjadi permas, orang-
orang tersebut hanyalah orang biasa
yang menjalani kehidupan sehari-hari
pada umumnya. Akan tetapi setelah men-
jadi permas, orang-orang tersebut tidak
boleh melakukan pekerjaannya lagi. Pe-
kerjaannya sekarang adalah ngayah pada
saat piodalan sebagai seruti banten (tu-
kang banten) dan ngayah Nampyog. Ti-
dak hanya di pura Samuantiga, permas
juga bisa ngayah sebagai seruti banten di
pura-pura seperti kahyangan tiga, dadia,
kawitan, maupun di pelangkiran balai
banjar di lingkungan desa pengemong
dengan syarat matur piuning Kehadapan
Ida Bhatara Samuantiga. Dengan men-
jadi permas orang-orang menyebutnya
Jero Permas. Berbicarapun dengan Jero
Permas biasanya dengan bahasa Bali ma-
dia atau halus" (wawancara 12 Juni
2016).

\section{Adanya perhatian dari paruman pura} Samuantiga

Berdasarkan hasil wawancara dengan Drs. I Wayan Patera, M.Hum pada tanggal 12 Juni 2016 menyatakan bahwa:
"Setiap berakhirnya upacara piodalan, paruman pura Samuantiga selalu mem- berikan penghargaan kepada parekan maupun para permas. Penghargaan itu diberikan karena telah melaksanakan ayahan dari sebelum berlangsungnya upacara sampai upacara berakhir kurang lebih selama dua bulan. Penghargaan (paica) itu dapat berupa pakaian dan ses- ari (uang)".

Pernyataan Drs. I Wayan Patera, M.Hum dibenarkan oleh Jero Permas Renis Kaca, yaitu sebagai berikut. 
"Memang benar saya dapat paica dari pura Samuantiga yang diberikan oleh paruman. Saya sangat bersyukur Kehadapan Ida Sesuhunan dan berterima kasih kepada paruman atas perhatiannya. Bagi saya dapat atau tidak dapat paica yang penting dapat ngayah dengan tulus dan memperoleh kerahayuan serta keselamatan" (wawancara 12 Juni 2016).

Dari beberapa pernyataan dan hasil wawancara di atas, ternyata ada perhatian dari Paruman pura Samuantiga dapat menambah eksisnya tari Nampyog dalam upacara piodalan di pura Samuantiga.

Bertahannya seni sakral dalam masyarakat adalah karena masyarakat yang memeluk agama Hindu masih memerankan seni sakral itu dalam setiap kegiatan keagamaan. Serta dipercaya dalam pementasan seni sakral terkandung makna ganda yaitu seni sebagai hiburan jasmani dan rohani, serta seni sebagai media penerangan ajaran agama. Hal tersebutlah sebagai penguat sehingga seni sakral bisa bertahan hidup sampai saat ini. Di samping itu yang terpenting sebagai penyebab seni sakral masih eksis dalam kehidupan keagamaan di Bali adalah dengan adanya sumber sejarah atau mitologi yang meng- haruskan setiap pelaksanaan yadnya untuk mementaskan seni sakral.

\section{P E N U T U P}

Keberadaan Tari Nampyog yang disakralkan dan dipentaskan di pura Samuantiga desa Bedulu, Kecamatan Blahbatuh, Kabupaten Gianyar mempunyai keunikan-keunikan antara lain 1) tari Nampyog merupakan tarian sebagai pelengkap dari rangkaian upacara piodalan di Pura Samuantiga yang bermakna penyucian dalam rangkaian Ida Bhatara akan tedun dan penetralisir mrana (wabah penyakit) 2) penari tari Nampyog adalah wanita yang tidak mengalami menstruasi lagi (menopause). 3) penari tari Nampyog adalah orang-orang yang berkomitmen untuk menjadi pengayah seumur hidupnya yang disebut dengan permas. 4) apabila pengayah permas ini tidak mampu lagi menjadi pengayah, maka akan diteruskan oleh pewarisnya (berdasarkan keturunan) 5) tari Nampyog ini diiringi oleh beberapa gamelan (gong, angklung) secara bersamaan yang ngayah saat upacara piodalan. 6) tari Nampyog yang disakralkan ini dipentaskan hanya pada saat upacara piodalan di pura Samuantiga desa Bedulu, Kecamatan Blahbatuh, Kabupaten Gianyar.

\section{DAFTAR PUSTAKA}

Adian, Dony Gahral, 2005. Percik Pemikiran Kontemporer : Sebuah Pengantar Komprehensif. Yogyakarta : Jalasutra.

Artadi, I Ketut, 2004. Nilai Makna dan Martabat Kebudayaan. Denpasar : Sinai. , 2009. Kebudayaan Spiritualitas. Denpasar : Pustaka Bali Post.

Arwati, Ni Made Sri, 1999. Upacara Upakara, Denpasar : Upada Sastra.

Astawa, A.A.Gede Oka dkk, 2006. Pura Samuantiga Bedulu Gianyar. Gianyar : Pemerintah Kabupaten Gianyar dan Paruman Pura Samuantiga Bedulu.

Azwar, Saefuddin, 2007. Metode Penelitian, Yogyakarta : Pustaka Pelajar.

Bandem, I Made, 1982. Ensiklopedi Tari Bali, Denpasar : Akademi Seni Tari Indonesia. 1991. Tari-Tarian Bali dalam Upacara Agama Hindu Dharma, Sebuah Tulisan sebagai Bahan Penyuluhan. Denpasar : Parisadha Hindu Dharma. 1996. Etnologi Tari Bali. Denpasar : Penerbit Kanesius. 2004. Kaja dan Kelod. Tarian Bali dalam Transisi, Yogyakarta : Institut Seni Indonesia. 
Bogdan, Robert dan Steven J. Taylor, 1992. Pengantar Metode Penelitian Kualitatif, Surabaya : Usaha Nasional

Culler, Jonathan, 1996. Saursure (Rodyah dan Siti Suhayati, pentj). Jakarta : Pusat Pembinaan dan Pengembangan Bahasa.

Darmayasa, I Made, 1995. Canakya Niti Sastra, Denpasar : Dharma Narada.

Eka, 2009. Tari Tampyog di Desa Pekraman Calo Kecamatan Tegallalang, Kabupaten Gianyar, Sripsi IHDN Denpasar.

Endraswara, Suwardi, 2006. Metodologi Kebudayaan. Yogyakarta : Pustaka Widyatama.

Geria, Anak Agung Gde, 1976. Desa Bedulu, Denpasar : Proyek Sasana Budaya Bali.

Gulo, 2004. Metodologi Penelitian dan Analisisnya, Jakarta : Ghalia Indonesia.

Hadi, Sumandiyo, 2000. Seni dalam Ritual Agama. Yogyakarta : Institut Seni Indonesia.

Hassan, Iqbal, 2002. Metode Penelitian dan Analisisnya, Jakarta : Ghalia Indonesia.

Hoed, Benny H, 2011. Semiotik dan Dinamika Sosial Budaya. Depok : Komunitas Bambu.

Kahmad, Dandang. 2002. Sosiologi Agama. Bandung : PT. Remaja Rosdakarya.

Koentjaraningrat, 1977. Metode Penelitian Masyarakat, Jakarta : Gramedia.

2002. Les Formes Elementaries de la Vie Religius, Jakarta : PT. Gramedia Pustaka Utama.

2002. Kebudayaan Mentalitas dan Pembangunan. Jakarta: PT. Gramedia Pustaka Utama.

Mantra, I.B, 1996. Landasan Kebudayaan Bali, Denpasar : Yayasan Dharma Sastra

Mas Putra, Ny. I Gusti Ayu , 2006. Upakara Yadnya, Pemerintah Propinsi Bali.

Moleong, Lexy, 2002. Metodologi Penelitian Kualitatif, Bandung : PT. Remaja Rosdakarya. 2004. Metode Penelitian Kualitatif, Edisi Revisi I, Bandung : PT. Remaja Rosda Karya.

Mulyana, Dedi, 2003. Metode Penelitian Kualitatif, Bandung : PT. Remaja Rosda Karya.

Namawi, Hadari, 2005. Metode Penelitian Bidang Sosial, Yogyakarta : Gajah Mada University Press.

Nasution, S, 1988. Metode Penelitian Naturalistik/Kualitatif. Bandung : Tarsito

Nasution, 2003. Metode Penelitian Naturalisme Kualitatif, Bandung : Tarsito.

Niniek, Yusniati, 2004. Manusia dan Masyarakat, Bandung : Ganesha exact.

Ngurah, I Gusti Made, dkk, 2006. Pendidikan Agama Hindu untuk Perguruan Tinggi, Surabaya : Paramitha.

Noviantari, 2012. Pementasan Tari Rejang Sutri di Pura Desa dan Puseh Desa Pekraman Batuan Kecamatan Sukawati, Kabupaten Gianyar, Skripsi : IHDN Denpasar.

Parmajaya, I Putu Gede, 2007. Seni Sakral, Denpasar : Fakultas Dharma Acarya Institut Hindu Dharma Negeri Denpasar.

Patera I Wayan, 2004. Kahyangan Jagat Pura Samuantiga, Denpasar : Yayasan Pustaka Bali.

Piliang, Yasraf Amir, 2012. Semiotika dan Hipersemiotika : Kode, Gaya, dan Matinya Makna. Bandung : Matahari.

Poerwadarminta, W.J.S, 2007. Kamus Umum Bahasa Indonesia, Jakarta : Bali Pustaka.

Punyatmadja, I B. Oka, 1989. Panca Sraddha, Jakarta, Yayasan Dharma Serathi.

Redana, Made, 2006. Panduan Praktis Penulisan Karya Ilmiah dan Proposal Riset, Denpasar : IHDN.

Salam, H. Burhanuddin, 1996. Logika Material, Filsafat Ilmu Pengetahuan, Jakarta : Rineka Cipta.

Satori, 2010. Metodologi Penelitian Kualitatif, Bandung : Alfa Beta.

Setia, 2002. Mendebat Bali, Denpasar : PT. Pustaka Manik Geni.

Soedarsono, 2003. Seni Pertunjukan Indonesia di Era Globalisasi, Yogyakarta : Gajah Mada University

Press.

Soelaeman, Munandar, 1989. Ilmu Sosial Dasar, Bandung : Refika Aditama

Subagiasta, I Ketut, 2008. Pengantar Acara Agama Hindu. Surabaya : Paramitha.

Subagyo, 2004. Metode Penelitian, Bandung : Bhineka Cipta.

Sugiyono, 2007. Memahami Penelitian Kualitatif, Bandung : Alfa Beta.

Sujarwa, 2010. Ilmu Sosial dan Budaya Dasar, Yogyakarta : Pustaka Belajar.

Suka Yasa, I Wayan, 2010. Agama dan Religiusitas. Pemahaman Konsep Spirit Hindu di Indonesia, Denpasar : Widya Dharma.

Suprayoga, 2001. Metode Penelitian. Jakarta : PT. Raja Grafindo Persada. 
Suprayoga dan Tabroni, 2001. Metodelogi Penelitian Sosial Agama. Bandung : PT. Remaja Rosda Karya.

Surayin, Ida Ayu Putu, 2005. Melangkah ke Arah Persiapan Upakara Upacara Yadnya, Denpasar : Upada Sastra.

Sutrisno, Muji dan Krisvernaak, 1993. Estetika Filsafat Keindahan. Yogyakarta : Kanisius.

Sutopo, H.B, 2002. Metodologi Penelitian Kualitatif-Dasar Teori dan Terapannya dalam Penelitian, Surakarta : Sebelas Maret University Press.

Sutrisno, Hadi, 1994. Metodologi Research, Yogyakarta : Yayasan Penerbit Fakultas Psikologi Universitas Gajah Mada.

Swastika, Drs. I Ketut Pasek, 2008. Arti dan Makna Puja Trisandya-Panca Sembah. Denpasar : CV. Kayumas Agung.

Tim Penyusun Kamus, 1993. Kamus Bahasa Bali Indonesia, Denpasar : Dinas Pendidikan Dasar Provinsi Bali.

Tim Penyusun, 2002. Kamus Besar Bahasa Indonesia, Pusat Bahasa Departemen Pendidikan Nasional, Jakarta : Balai Pustaka.

Tri Guna, I B. Yudha, 1997. Metode Kelas, Konflik dan Penafsiran Kembali, Simbolis Masyarakat Hindu di Bali, Bandung : Universitas Padjajaran.

Titib, 2003. Teologi dan Simbol-Simbol dalam Agama Hindu, Surabaya : Paramitha.

Wiana, Drs. I Ketut, 2003. Makna Upacara Yadnya dalam Agama Hindu. Surabaya : Paramitha.

Yudabakti I Made, Watra I Wayan, 2007. Fildafat Seni Sakral dalam Kebudayaan Bali, Surabaya : Paramita.

Zamroni, 1992. Pengantar Pengembangan Teori Sosial, Yogyakarta : Tiara Wacana 